\title{
Adaptation of ATI-R Scale to Turkish Samples: Validity and Reliability Analyses
}

\author{
Erdoğan TEZCi ${ }^{1}$ \\ ${ }^{1}$ Necatibey Education Faculty, Balıkesir University, Balıkesir, Turkey \\ Correspondence: Erdoğan TEZCI, Necatibey Education Faculty, Balıkesir University, Dinkçiler M. 10100 \\ Balıkesir, Turkey. E-mail: erdogan.tezci@gmail.com
}

Received: July 15, 2016

doi:10.5539/ies.v10n1p67

\author{
Accepted: August 19, 2016 \\ Online Published: December 24, 2016 \\ URL: http://dx.doi.org/10.5539/ies.v10n1p67
}

\begin{abstract}
Teachers' teaching approaches have become an important issue in the search of quality in education and teaching because of their effect on students' learning. Improvements in teachers' knowledge and awareness of their own teaching approaches enable them to adopt teaching process in accordance with their students' learning styles. The Approaches to Teaching Inventory (ATI-R), which has been developed and revised in this framework, is a scale which is effectively used to define teaching approaches in different cultures. Originally written in English, the ATI-R's validity and reliability results were very positive. The scale's validity and reliability analyses in different languages and cultures have produced a wide range of different results. The aim of this paper is to adapt the scale in the Turkish language. Firstly, in order to handle linguistic equivalence, data collected from 40 teachers were analyzed, and then for confirmatory and reliability analyses data were collected from 485 teachers. According to the analyses, the scale has two dimensions, and under these two dimensions there are four sub-factors. Reliability and validity results in Turkish culture are also acceptable. As a result, the scale can be administered to define teachers' teaching approaches in Turkish samples.
\end{abstract}

Keywords: teacher education, approach to teaching inventory (ATI), cross-cultural validity, Turkish version

\section{Introduction}

Educational reform, in fact, means to switch from teacher-centered approaches to student-centered educational activities (Yanpar-Yelken, \& Kilıç, 2010). The success of these reforms is possible when teachers use student-focused approaches in teaching and learning activities instead of teacher-focused approaches (Ho, 1998; Gibbs \& Coffey, 2004). Postareff and Lindblom-Ylänne (2008) indicated that student-focused education is needed to increase the quality of education. Many studies have indicated that teachers' teaching perceptions deeply affect their teaching approaches and their teaching approaches profoundly affect students' learning approaches (Coffey \& Gibbs, 2000; Gibbs \& Coffey, 2004; Lindblom-Ylänne, Trigwell, Nevgi, \& Ashwin, 2004; Trigwell, Prosser, \& Waterhouse, 1999).

According to the research results on teachers' teaching approaches, students whose teachers received training in teaching approaches showed deeper learning approaches than the students whose teachers did not received training in teaching approaches (Entwistle \& Ramsden, 1983; Trigwell et al., 1999). As teachers' teaching approaches affected students' learning, student-focused education approaches have become the central subject in both pre-service and in-service education of teachers (Alkin-Sahin, 2015; Biggs, 1993). Teachers' perception towards teaching affects their teaching behaviour. For this reason, both pre-service and in-service education, it is aimed at changing this perception and raising knowledge and experiences serving a student-focused teaching approach (Biggs, 2003; Kember \& Kwan, 2000; Postareff, Lindblom-Ylänne, \& Nevgi, 2007; Wilson \& Berne, 1999). However, the results of such training are inconclusive because there is a lack of evidence of whether this perception is raised or not. "Studies of the evaluation of the tranings are generally about teachers' satisfaction about the given training courses, but the number of studies showing the effect of the trainings on their daily teaching practice is very limited" (Stes, De Maeyer, \& Van Petegem, 2010, p. 187).

Analyzing the effect of these teacher training activities on teachers' perceptions will be useful in terms of understanding the contribution of these reformist activities. Especially, defining the effectiveness of these training efforts in pre-service teacher training will shed light on the success of the pre-service teacher training curricula. The idea of having consistency between teachers' teaching approaches and students' learning 
approaches (Prosser \& Trigwell, 1999; Trigwell, Prosser, \& Taylor, 1994; Zhang \& Sternberg, 2000) supported shifting from a teacher-focused approach to a student-focused approach. The reason for this support is that it is believed that a learner-centered approach will have a meaningful effect on learning outcomes. Many studies (Coffey \& Gibbs, 2000; Friedlan, 1995; Gibbs \& Coffey, 2004; Ho, Watkins, \& Kelly, 2001; Kember \& Gov, 19994; Trigwell et al., 1994) support this idea.

In teacher-centered teaching, students use superficial learning approaches and also focus on the reproduction of knowledge. If teachers use student-focused teaching approaches instead of teacher-centered teaching, students tend to use deep learning approaches (Gow \& Kember, 1993; Trigwell et al., 1999). When the effects of teachers' teaching approaches on students' learning approaches are considered (Kember \& Gow, 1994; Prosser \& Trigwell, 1997; Stes et al., 2010; Trigwell et al., 1994), determining teachers' teaching approach may contribute solutions to the quality problems in education. Kember (1997, p. 273) indicates the importance of studying the teaching approach by saying "the studies have been shown to be related to measures of the quality of student learning". Furthermore, increasing teachers' own awareness of their teaching behaviors raises the quality of teaching (Postareff et al., 2007).

According to Prosser and Trigwell (1999), teachers' teaching approaches also affect their perceptions of their working environment. Defining the relationship between teachers' teaching approaches and students' behaviors enable teachers to adapt their teaching approaches in accordance with students' learning approaches (Fenstermacher \& Soltis, 2004). In order to develop teaching activities in the classroom and to create a more effective learning atmosphere, teaching approaches were classified (Banning, 2005; Barr \& Tagg, 1995; Ertmer \& Newby, 1993; Fenstermacher \& Soltis, 2004; Gow \& Kember, 1993; Kember, 1997; Jonassen, 1990). For example, Gow and Kember (1993) classified teaching approaches as transmitting knowledge and facilitating learning.

On the other hand, Trigwell and Prosser $(1996,1999,2006)$ classified teaching approaches as teacher- and student-focused approaches. Teacher- or student-focused approaches are the most common terms and the terms can be defined as umbrella terms for many classification categories (Kember, 1997). Prosser and Trigwell (1993, 1999) developed the Approaches to Teaching Inventory (ATI) scale for student-focused and teacher-focused teaching approaches, and later researchers have revised the scale. The scale is used for discriminating approaches from the Information Transmission/Teacher-Focused (ITTF) approaches to Conceptual Change/Student-Focused (CCSF) approaches. The scale focuses on 4 different teaching intentions: transmission of information, concept acquisition, conceptual development and conceptual change, and it also focuses on defining 3 teaching strategies as teacher-focused, student-teacher interaction and student-focused teaching strategy. The scale was effectively used in many studies (Gibbs \& Coffey, 2004; Postareff et al., 2007; Stes et al., 2010).

The scale has many advantages, such as ease of use and the gathering of data from a large sample. Furthermore, the scale produced very distinctive results in many studies (Lindblom-Ylänne, Trigwell, Nevgi, \& Ashwin, 2006; Lueddeke, 2003; Nevgi, Postareff, \& Lindblom-Ylänne, 2004; Singer, 1996; Stes et al., 2010) to distinguish the teachers having a student-focused teaching approach from the teachers having a teacher-focused teaching approach (e.g., teachers from hard disciplines tended to have an information transmission/teacher-focused approach to teaching, while teachers from soft disciplines took a more conceptual change/student focused approach to teaching).

The ATI scale was originally developed to determine university science teachers' approaches to teaching based on a phenomenological study in Australia. The revised version of the ATI (ATI-R) is aimed not only at science teachers' teaching approaches but also at teachers in various other disciplines (Prosser \& Trigwell, 2007). The aim of this paper is to adapt the revised version of ATI (ATI-R) to Turkish culture. The scale has been adapted to different cultures with different reliability and validity levels. Stes, Gijbels, and Van Petegem (2008) found that the CCSF scale was valid in German sampling; however, the ITTF scale was not valid for the same sampling group. Stes et al. (2010) analysed the Dutch version again and found the two dimensions and five sub-factors by using higher reliability scores.

On the other hand, Schellhase (2009) reported a satisfactory level of Cronbach alpha as an evidence of reliability for his scale. Zhang (2001a, 2004) adapted this scale to Chinese culture and found similar results regarding the validity and reliability similar reliability and validity like those of Trigwell and Prosser (1996). Studies showed that the scale is content oriented, and for this reason instead of directly using the scale, it should be adapted and its validity and reliability values for different cultures should be defined (Meyer \& Eley, 2006). Analyzing the scale for different cultures can increase its usage in different cultures. In this sense, the research question is required to be 'reliable and valid enough to determine in defining pre-service teachers' approaches to teaching'. 


\section{Theoretical Background of ATI}

The ATI Scale is based on the teacher-centered teaching approach focusing on transmitting the knowledge to students and student-centered teaching approaches focusing on facilitating teaching. The shift from teacher-focused teaching approaches to student-focused teaching approaches may be derived from constructivist ideas in education (Ertmer \& Newby, 1993). The teacher-focused teaching approach is to transfer the knowledge to students and elicit students' reproduction of that knowledge. Teaching is seen as transferring knowledge by teachers who see learning as assimilating the external reality (Tezci \& Gürol, 2003). Content is constructed by the teachers. These teachers ignore pre-learnings, existing beliefs and knowledge, readiness and experiences. They focus on surface learning instead of deep learning (Biggs, 1979; Gibbs \& Coffey, 2004). This situation causes a consumption of knowledge rather than the production of it. Teacher-focused teaching is qualitative without considering the results of the teaching process and students' understanding of the knowledge.

The teacher-focused teaching approach can be considered as traditional teaching approaches which are against the constructivist approach (Jonassen, 1990; Gürol, 2005; Yanpar-Yelken \& Kıllıc, 2010). Kember (1997) describes the teacher-focused teaching approach as content oriented teaching by transferring knowledge. Teachers who adopted a teacher-focused approach see students as empty vessels, passive recipients of information, and teachers dominate learning, using local and conservative thinking forms (Zhang, 2001b). In the teacher centered teahing approach a teacher adopts teaching methods with transmitting to students accurate versions of the universal body of truths. Students's prior knowledge is not taken into account in the teaching and learning process.

The student-focused teaching approach focuses on developing deeper learnings (Biggs, 1979) and has an understanding of the need to support learners' intellectual development. In this approach, teachers are facilitators of learning; the focus is on the learners rather than on teachers or content. These teachers give importance improving students' own understanding. They also take into account students' pre-learnings, readiness, beliefs and needs (Biggs, 1999; Kember \& Kwan, 2002; Prosser, et al., 1994; Trigwell et al., 1999). The student-focused teaching approach has a similar understanding to constructivism, and aims to achieve both learning progress and intellectual development in students.

Learners actively construct their own learning, and in this respect the student-focused teaching approach is based on a constructivist perspective. In the student-focused approach, teachers let their students make their own decisions and construct their own intellectual autonomy. Assessing students' learnings is done with a variety of different approaches (Postareff \& Lindblom-Ylänne, 2008; Zhang, 2001a). Coffey and Gibbs (2002) asserted that student-focused teachers use more different types of teaching methods than teacher-focused ones. In many studies it was also found that the students of student-focused teachers understand the concepts more deeply than those of teacher-focused teachers (Gibbs \& Coffey, 2004; Ho et al., 2001; Kember \& Gow, 1994; Prosser \& Trigwell, 2006).

Trigwell et al. (1994, p. 78) identified five different approaches to teaching:

(A) A teacher-focused strategy with the intention of transmitting information to students;

(B) A teacher-focused strategy with the intention that students acquire the concepts of the discipline;

(C) A teacher/student interaction strategy with the intention that students acquire the concepts of the discipline;

(D) A student-focused strategy aimed at students developing their conceptions; and

(E) A student-focused strategy aimed at students changing their conceptions.

Trigwell and Prosser $(2004$; 1996) developed ATI, which is based on the results of phenomenological analyses, to measure teachers' approaches to teaching. Research was conducted with lecturers in universities. The scale originally consisted of 16 items (Trigwell \& Prosser, 2004). Prosser and Trigwell (2006) gathered data from 1000 university teachers from different faculties. In order to determine the factor structure, a tor analysis was conducted. According to the results of their analysis, the scale consists of two factor structures (conceptual change/student focused-CCSF and information transmission/teacher focus-ITTF) and supports four factor models. Later, researchers decided to increase the number of the items and revised the scale. The revised version of the scale has 22 items. Half of the items are for measuring the teacher-focused approach and the rest are for measuring the student-focused approach (Trigwell, Prosser \& Ginns, 2005). The ATI-R has two dimensions. The first dimension is ITTF, which is based on the teacher-centered approach and the second is CCSF, which is based on the student-centered approach. According to Trigwell et al. (2005), although communications items which were in the ITTF approach were also seen in the CCFS, the student-focused items in CCSF were not seen in the ITTF. The CSSF approach has a more complex structure. 
Prosser and Trigwell (2006: 416) drew attention to three different points which cause misuse of the scale. The first point is that it is impossible to categorise teachers as teacher- or student-focused according to the marks taken from the scale, the second is that the scores cannot be used for comparing teaching dimensions of teachers and the last is that the scale cannot depict all aspects of the teaching process. According to reseachers, the scale can be used for changes in teachers' understanding and for determining the relationship between other factors related to teaching and learning environments. Anaysing the scale's reliability and validity for different cultures will contribute to more widespread usage of the scale around the world.

\section{Method}

\subsection{Participants}

Research was conducted with two different samplings. The first group, of 40, was selected from pre-service students from an English Language Teaching Department in order to get linguistic equivalence. 22 were female $(55 \%)$ and $18(45 \%)$ were male. The second group, on which validity and reliability analyses were conducted, was comprised of 485 students from 8 different departments. 260 (54\%) of the participants did not attend any pedagogy classes, and the rest, 225 (46\%), had already completed the pedagogy classes. $245(51 \%)$ of the participants were attending soft discipline departments such as history, geography and literature, and the rest, 240 (49\%), were attending hard science departments such as mathematic, physics and chemistry. 290 (59.79\%) of the participants were female and the $195(40.21 \%)$ of the participants were male. The research was conducted with the pre-service teachers, $215(44.33 \%)$ of whom were freshmen first graders and $270(55.67 \%)$ of them were seniors, attending an education faculty during the 2015-2016 academic year.

\subsection{Data Collection Tool}

The scale 'Revised Teaching Approach Scale (ATI-R)' to be adopted was first developed in 1996 by Trigwell and Prosser (Prosser et al., 1999; Trigwell et al., 1994). The ATI-R was developed to define the relationship between the teaching approaches of science teachers and the learning approaches of science students. The scale was used to define teachers' teaching approaches in different fields (Gibbs \& Coffey, 2004; Postareff et al., 2008; Stes et al., 2010; Trigwell, 2002). The first version of the scale consisted of two factors, four dimensions and 16 items. Eight items of the scale reflected a teacher-centered /information transmission approach, and the other eight items reflected a conceptual change/student-focused approach. The scale aimed at measuring four educational aims, information transmission, concept acquisition, conceptual development and conceptual change, and three strategies, the teacher-focused approach, teacher-student interaction and the student-focused approach. Trigwell and Prosser (2004) defined two factors, the information transmission/teacher-focused approach and the conceptual change/student-focused teaching approach, in their valididity and reliability analysis with 650 participants. Cronbach's Alpha coefficiency of the conceptual change/student focused approach was 0.75, and the information transmission/teacher-focused approach's Cronbach Alpha coefficiency was defined as 0.73 .

Prosser and Trigwell (2006) also conducted confirmatory factor analysis by using the data taken from 1000 university teachers from different fields and countries. In that analysis it was found that the scale had two factors and supports a four factor model. It was also found that the information transmission/teacher-focused (ITTF) factor has two dimensions, information transmission (IT) and teacher-focused (TF); the conceptual change/student-focused factor has two dimensions, conceptual change and student-focused teaching approach. The scale consisted of four dimensions in total.

The present version of the scale has 22 items, because after revision 10 extra items have been added to the scale. During the revision, only one item was excluded from the scale and a few items were rewritten in order to get more fluent sentence structures. Originally, the version of ATI-R developed by Trigwell et al. (2005) had 25 items, but three items were excluded from the scale because they had low factor loadings. Validity and reliability analyses were conducted on 318 participants working as academics in Australian and British universities. Confirmatory analyses of the scale have adequate fitting indexes (CFI $=0.95$, NNFI $=0.94$; RMSEA $=0.06$; SRMR $=0.08$ ). The validity analysis of the CCSF approach dimension was found as .86 , and the ITTF dimension validity was calculated as .83 . Trigwell et al. (2005) found negative meaningful correlation $(r=-0.36)$ between CCSF and ITTF.

ATI-R is a five Likert scale. The scale is scored as: only rarely/never $=1$, sometimes $=2$, about half the time $=3$, frequently $=4$ and almost always or always $=5$. All the items in the scale are positively formulated. The scale is intended to classify the participants; it presents their understanding of their beliefs about teaching fields. Items 1 , $2,4,6,9,10,11,12,16,19$ and 22 reflect an information transmission/teacher-focused approach and items 3,5 , $7,8,13,14,15,17,18,20,21$ reflect a conceptual change/student-focused approach (Trigwell et al., 2005). The highest score on the scale is 110 and the lowest is 22 . 


\subsection{Analysis of Data and Applications}

Firstly, the scale was translated into Turkish to provide linguistic equivalence. In some studies (Meyer \& Eley, 2006; Schellhase, 2009; Stes et al., 2010) validity and reliabity problems were seen because of the translation and further research on this problem is needed. Linguistic equivalence is an important issue for validity and reliabity problems derived from cultural and linguistic differences in the adaptation of scales (Geisinger, 1994). In this study, for linguistic equivalence the scale was translated with the help of experts in teaching English and English Language and Literature whose native language is Turkish.

In the second phase, the translated form was analyzed by the Turkish speaking experts whose native language is English. Then the same form was translated again into English by two bilingual experts, one of whom is a native speaker of English and the other a native speaker of Turkish. The retranslated form was compared with the original form. After this process, the final version of the scale was completed. The English and Turkish versions of the scale were administered to pre-service teachers in English Language Teaching Department over 20 days. The correlation co-efficacy was analyzed (Karataş \& Erden, 2012; Özgüven, 1994; Savaşır, 1994; Tavşancıl, 2002; Tekin, 1996).

In the third phase, Confirmatory Factor Analyses (CFA) was done to check the scale's suitability to Turkish culture. CFA is a process to form a latent variable by using observed ones via a pre-determined model. CFA is used to determine the structure a priori (Büyüköztürk, Çokluk, \& Şekercioğlu, 2010; Kline, 2011). CFA is also used for designing, revising, defining and verifying the relationships among variables of the hypothesis of a scale (Bentler \& Bonett, 1980).

Different indices were used to define the suitability of the factor structure. The first was chi-square and the $p$ value related to the chi-square. The chi-square value is affected by sample size (Brown, 2006; Kline, 2011). The chi-square value can be used when the sample size consists of between 250-500 participants (Bollen, 1989). The sample in this study consisted of 480 participants. In this respect, the sampling size is suitable for using the chi-square value. When the Goodness Fit Index (GFI) and the Adjusted Goodness of Fit Index (AGFI), which are alternatives to the chi-square index, are around 1, they indicate an excellent fit. The other fitting indexes analyzed in this study were the Root Mean Square Error of Approximation (RMSEA), the Root Mean Residual (RMR) and the Standardized Root Mean Square Residual (SRMR). Another fitting index affected by sample volume and effectively used with small sampling group is the Comparative Fit Index (CFI). The Normed Fit Index (NFI) and the Non-Normed Fit Index (NNFI) which gives values independently from the chi-square, and the Parsimony Goodness-of-Fit Index (PGFI), which gives information about the simplicity of the model, were the other indexes utilized in the research (Bollen 1989; Hoyle 1995; Jöreskog and Sörbom, 1996; Tabachnick and Fidell, 2007). Furthermore, the Akaike Information Criterion (AIC) and the Consistent Akaike Information Criterion (Saturated-CAIC), EVCI which are less affected by degree of freedom were used to define which version of the model is more suitable. Both of these indexes had low values, indicating the suitability of the data for the model.

In many studies (Lueddeke, 2003; Lindblom-Ylänne et al., 2004; Lindblom-Ylänne et al., 2006; Trigwell, 2002), the scale was used to define the teaching approaches of teachers and lecturers who study hard and soft sciences. It was also seen that teachers and lecturers teaching soft sciences had higher scores on the CCSF. In this study, pre-service teachers and students were compared with students in soft science departments.

\section{Results}

\subsection{Results Related to Linguistic Equivalence}

Trigwell and Prosser (2006) indicated that the ATI-R has two factors, Information Transmission/Teacher Focused (ITTF) and Conceptual Change/Student-Focused (CCSF). For this reason, the first analysis was constructed on the basis of these two factors. Turkish and English versions of the scale were applied to 40 pre-service teachers with 20 days intermittency to get linguistic equivalence.

Firstly, the original version of the scale was applied, and later the Turkish version. The scattering of the scores taken from the scales were analyzed and to define the normal distribution Kolmogorov-Smirnov $\mathrm{Z}$ analysis was conducted. The results are given on Table 1 . 
Table 1. Kolmogrov Smirnov Z Test results related to normal distribution

\begin{tabular}{|c|c|c|c|c|c|}
\hline & & \multicolumn{4}{|c|}{ ITTF Turkish Version CCSF Turkish Version ITTF English Version CCSF English Version } \\
\hline & $\mathrm{N}$ & 40 & 40 & 40 & 40 \\
\hline \multirow[t]{2}{*}{ Normal Parameters } & Mean $(\mathrm{M})$ & 42.3000 & 43.5000 & 42.9250 & 43.8500 \\
\hline & Standard Deviation $(\mathrm{Sd})$ & 5.27306 & 4,54042 & 5.82386 & 4.91752 \\
\hline \multicolumn{2}{|c|}{ Kolmogorov-Smirnov Z } & .807 & .575 & .920 & .513 \\
\hline \multicolumn{2}{|l|}{ Significance } & $.532 *$ & $.895^{*}$ & $.365^{*}$ & $.955^{*}$ \\
\hline \multicolumn{6}{|c|}{ a. Test distribution is normal } \\
\hline
\end{tabular}

According to the results, each factor of the scale's Turkish and English versions were normally distributed $(\mathrm{p}>$.05). Having such scores enabled the use of the Pearson Moment Correlation analysis. On Table 2, correlation analyses of the results of each item are given for both versions.

Table 2. Correlation and t test analysis results

\begin{tabular}{|c|c|c|c|c|c|c|c|c|c|}
\hline \multicolumn{5}{|c|}{ ITTF } & & \multicolumn{4}{|c|}{ CCSF } \\
\hline $\begin{array}{l}\text { Items } \\
\text { Number }\end{array}$ & $\mathrm{M}$ & $\mathrm{Sd}$ & $\mathrm{r}$ & $\mathrm{t}$ & $\begin{array}{l}\text { Items } \\
\text { Number }\end{array}$ & M & $\mathrm{Sd}$ & $\mathrm{r}$ & $\mathrm{t}$ \\
\hline \multirow{2}{*}{1} & 4.03 & .83 & \multirow{2}{*}{$.64 *$} & \multirow{2}{*}{$.650 * *$} & \multirow{2}{*}{3} & 3.93 & .97 & \multirow{2}{*}{$.69 *$} & \multirow{2}{*}{$1.000 * *$} \\
\hline & 3.95 & .88 & & & & 3.80 & 1.02 & & \\
\hline \multirow{2}{*}{2} & 4.05 & .96 & \multirow{2}{*}{$.63^{*}$} & \multirow{2}{*}{$1.537 * *$} & \multirow{2}{*}{5} & 3.58 & .87 & \multirow{2}{*}{$.79 *$} & \multirow{2}{*}{$.771 * *$} \\
\hline & 3.85 & .95 & & & & 3.50 & .96 & & \\
\hline \multirow{2}{*}{4} & 3.95 & .90 & \multirow{2}{*}{$.63^{*}$} & \multirow{2}{*}{$-.813^{* *}$} & \multirow{2}{*}{7} & 3.58 & 1.30 & \multirow{2}{*}{$.81 *$} & \multirow{2}{*}{$-.198 * *$} \\
\hline & 4.05 & .90 & & & & 3.60 & 1.29 & & \\
\hline \multirow{2}{*}{6} & 4.05 & .93 & \multirow{2}{*}{$.46^{*}$} & \multirow{2}{*}{$-1.423 * *$} & \multirow{2}{*}{8} & 3.15 & .98 & \multirow{2}{*}{$.61 *$} & \multirow{2}{*}{$.726^{* *}$} \\
\hline & 3.83 & .98 & & & & 3.05 & .99 & & \\
\hline \multirow{2}{*}{9} & 3.93 & .76 & \multirow{2}{*}{$.81^{*}$} & \multirow{2}{*}{$-1.000 * *$} & \multirow{2}{*}{13} & 3.70 & 1.11 & \multirow{2}{*}{$.82 *$} & $467 * *$ \\
\hline & 4.00 & .78 & & & & 3.65 & 1.12 & & $.40 / \cdots$ \\
\hline 10 & 3.60 & 1.01 & $70 *$ & $-621 * *$ & 14 & 3.83 & 1.04 & $79 *$ & $-227 * *$ \\
\hline 10 & 3.68 & .97 & .10 & -.021 & 14 & 3.85 & 1.10 & .19 & -.2217 \\
\hline 11 & 3.85 & .89 & $73 *$ & $-495 * *$ & 15 & 3.63 & 1.08 & $63 *$ & $172 * *$ \\
\hline 11 & 3.90 & .84 & .13 & -.495 & 15 & 3.60 & 1.06 & .03 & $.1 / 2$ m \\
\hline 12 & 4.35 & .86 & $71 *$ & $216 * *$ & 17 & 4.28 & .88 & $74 *$ & $723 * *$ \\
\hline 12 & 4.33 & 1.02 & .114 & $.210^{\circ}$ & 17 & 4.20 & .94 & & .1250 \\
\hline 16 & 4.53 & .51 & $78 *$ & $443 * *$ & 18 & 3.83 & 1.17 & $70 *$ & $422 * *$ \\
\hline 10 & 4.55 & .55 & .18 & $-.443^{n}$ & 18 & 3.78 & 1.14 & $.19^{\circ}$ & $.4 \angle 2 \cdots$ \\
\hline 19 & 4.18 & .81 & $54 *$ & $-595 * *$ & 20 & 3.88 & .91 & $71 *$ & $-227 * *$ \\
\hline & 4.25 & .84 & $.54^{\circ}$ & -.595 & 20 & 3.90 & .92 & .11 & -.2217 \\
\hline 27 & 4.05 & .88 & $53 *$ & $752 * *$ & 21 & 3.90 & 1.03 & & \\
\hline 22 & 4.15 & .86 & $.53^{\prime \prime}$ & $-.152^{*+6}$ & 21 & 3.93 & 1.04 & $.06^{*}$ & $-.185^{*}$ \\
\hline Entire & 4.05 & .35 & $86 *$ & $.037 * *$ & Entire & 3.66 & .82 & $.80 *$ & $199 * *$ \\
\hline ITTF & 4.04 & .47 & .00 & & CCSF & 3.65 & .86 & & .197 \\
\hline
\end{tabular}

$* \mathrm{p}<.001 ; *{ }^{*} \mathrm{p}>.05$

According to the results, all items in the scales showed meaningful correlation $(\mathrm{p}<.001)$. In the ITTF approach, the highest correlation score $(r=.81 ; \mathrm{p}<.001)$ was found for item 9 , the lowest $(\mathrm{r}=.46 ; \mathrm{p}<.001)$ was found for item 6. In the CCSF approach, the highest correlation score $(\mathrm{r}=.82 ; \mathrm{p}<.001)$ was found for item 13 , and the lowest correlation $(\mathrm{r}=.61 ; \mathrm{p}<.001)$ was seen for item 8. Positive medium or high levels of correlations were found for all items. Paired Sample t Test results indicate that all items were not significant ( $p>.05)$. A negative correlation was found in the Turkish $(r=-.28 ; \mathrm{p}<.01)$ and English $(\mathrm{r}=-.32 ; \mathrm{p}<.05)$ versions of ITTF and CCSF. Analysis results 
showed that the English and Turkish versions of the scale had linguistic equivalence.

\subsection{Results Related to Reliability}

The scale's Cronbach Alpha coefficiency value was calculated based on two factors. For the ITTF sub-factor Cronbach Alpha coefficiency was found to be 0.93 , for the CCSF sub-factor Cronbach Alpha coefficiency was found to be 0.87 . Cronbach Alpha coefficiency of the entire scale was found to be 0.81 .

\subsection{Results Related to CFA}

CFA was conducted to define the dimensions of the scale. The first analysis was conducted on ITTF and CCSF considering two factors. Chi-square value $\left(X^{2}\right)$ was found as $1179.25(\mathrm{df}=208)$. Calculated fit indices are given on Table 3.

Table 3. Goodness-of-fit indices for CFA according to two factor model

\begin{tabular}{|c|c|c|c|c|c|c|c|c|c|c|c|c|c|}
\hline Fit Indices & $X^{2}$ & RMSEA & GFI & AGFI & CFI & NFI & NNFI & SRMR & RMR & IFI & AIC & CAIC & EVCI \\
\hline DFA value & $\begin{array}{c}1179.25 \\
(d f=208)\end{array}$ & .099 & .94 & .93 & .85 & .82 & .83 & .077 & .067 & .85 & 1157 & 1395.17 & 2.65 \\
\hline $\begin{array}{l}\text { Eight error } \\
\text { covariances }\end{array}$ & $\begin{array}{c}601.61 \\
(\mathrm{df}=196)\end{array}$ & .064 & .90 & .87 & .92 & .88 & .90 & .062 & .066 & .92 & 715 & 1013.42 & 1.142 \\
\hline
\end{tabular}

According to the results, the values related to the CFA were calculated as $X^{2} / \mathrm{df}=5.669$, RMSEA .099 ; $\mathrm{NNFI}=.83$ and CFI .85. The two-factor model showed a relatively poor fit to the data. Modifications were made for eight error variances; no improvement was seen in fit indices but the fit indices did not reach the desired values. For this reason, it was decided to use the four factor models indicated by Prosser and Trigwell (1999; 2004). It was decided to analyze within a two-dimension model (ITTF and CCSF) and four sub-factors (under the ITTF dimension, "Information Transmission [IT]" and "Teacher Focused Strategy [TFS]"; under the CCSF dimension "Concept Change [CC]" and "Students Focused Strategy [SFS]).

In order to decide which items were under which factors some other studies were analyzed (Postareff et al., 2007; Prosser \& Trigwell, 1996, 2004, 2006; Stes et al., 2010). The descriptive statistics and Cronbach alpha values for the four factor model are provided in Table 4.

Table 4. Distribution of the items to sub-factors and descriptive analysis results

\begin{tabular}{|c|c|c|c|c|c|c|c|c|}
\hline Dimensions & Sub-factors & Items & $\mathrm{N}$ & M & $\mathrm{Sd}$ & Skewness & Kurtosis & $\begin{array}{c}\text { Cronbach's } \\
\text { Alpha }\end{array}$ \\
\hline \multirow{11}{*}{$\begin{array}{c}\text { Information } \\
\text { Transmission/Teacher } \\
\text { Focused (ITTF) }\end{array}$} & \multirow{5}{*}{$\begin{array}{l}\text { Teacher Focused } \\
\text { Strategy (TFS) }\end{array}$} & TFS1 & 485 & 3.73 & 1.11 & -.728 & -.134 & \multirow{5}{*}{.84} \\
\hline & & TFS6 & 485 & 3.49 & 1.02 & -.379 & -.470 & \\
\hline & & TFS9 & 485 & 3.48 & 1.07 & -.461 & -.384 & \\
\hline & & TFS11 & 485 & 3.47 & 1.10 & -.384 & -.568 & \\
\hline & & TFS16 & 485 & 3.78 & 1.12 & -.607 & -.496 & \\
\hline & \multirow{6}{*}{$\begin{array}{c}\text { Information } \\
\text { Transmission (IF) }\end{array}$} & IFS2 & 485 & 3.60 & 1.13 & -.475 & -.570 & .89 \\
\hline & & IFS4 & 485 & 3.88 & 1.04 & -.729 & -.149 & \\
\hline & & IFS10 & 485 & 3.62 & 1.09 & -.505 & -.465 & \\
\hline & & IFS12 & 485 & 4.05 & 1.06 & -.943 & .016 & \\
\hline & & IFS19 & 485 & 3.95 & 1.10 & -.902 & -.003 & \\
\hline & & IFS22 & 485 & 3.89 & 1.11 & -.838 & -.049 & \\
\hline \multirow{4}{*}{$\begin{array}{c}\text { Conceptual Change/ } \\
\text { Student Focused } \\
\text { (CCSF) }\end{array}$} & \multirow{4}{*}{$\begin{array}{l}\text { Conceptual Change } \\
\text { (CC) }\end{array}$} & $\mathrm{CC} 3$ & 485 & 3.64 & 1.23 & -.643 & -.598 & .93 \\
\hline & & $\mathrm{CC} 5$ & 485 & 3.34 & 1.14 & -.320 & -.706 & \\
\hline & & $\mathrm{CC} 8$ & 485 & 3.12 & 1.19 & -.094 & -.809 & \\
\hline & & CC13 & 485 & 3.59 & 1.25 & -.582 & -.672 & \\
\hline
\end{tabular}




\begin{tabular}{ccccccccc}
\hline & CC17 & 485 & 3.69 & 1.22 & -.517 & -.913 & \\
\cline { 2 - 8 } & CC21 & 485 & 3.58 & 1.23 & -.555 & -.709 & \\
\cline { 2 - 8 } & SFS7 & 485 & 3.62 & 1.31 & -.598 & -.860 & .93 \\
\cline { 2 - 8 } & SFS14 & 485 & 3.47 & 1.26 & -.375 & -.976 & \\
\cline { 3 - 8 } Stratent Focused (SFS) & SFS15 & 485 & 3.27 & 1.20 & -.268 & -.858 & \\
\cline { 2 - 8 } & SFS18 & 485 & 3.71 & 1.32 & -.633 & -.897 & -.822 \\
\hline
\end{tabular}

According to the analysis, the results were $X^{2}=403.23(\mathrm{df}=204), \mathrm{X}^{2} / \mathrm{df}=1.98$. When this value is lower than 3 , it indicates excellent fit. The other fitting indexes are given in Table 5.

Table 5. Fitting indexes of DFA for four factors structure

\begin{tabular}{|c|c|c|c|c|c|c|c|c|c|c|c|c|c|}
\hline Indices & $X^{2}$ & RMSEA & GFI & AGFI & CFI & NFI & NNFI & SRMR & RMR & IFI & AIC & CAIC & EVCI \\
\hline $\begin{array}{l}\text { DFA } \\
\text { Value }\end{array}$ & $\begin{array}{c}403.23 \\
(\mathrm{sd}=204)\end{array}$ & .045 & .93 & .91 & .98 & .97 & .98 & .041 & .054 & .98 & 506.00 & 764 & 1.05 \\
\hline
\end{tabular}

The analysis for the four factor model (NNFI=.98, NFI=.97, RMR=.054, SRMR=.041; GFI=.93; AGFI=.91, $\mathrm{CFI}=.98$ ) indicated good fit indices. When proposed modifications were made for error variances (items 8 and 15 , 9 and 11), the desired improvement was not observed in the fit indices. The only changes were seen in CAIC, 758 , and $X^{2}$ values $\left(X^{2} / \mathrm{df}=398 / 202=1.97\right)$. It was seen that fit indices of the model not containing error variance were suitable for the data. The standardized parameters for four sub-factors of the scale are given on Figure 1.

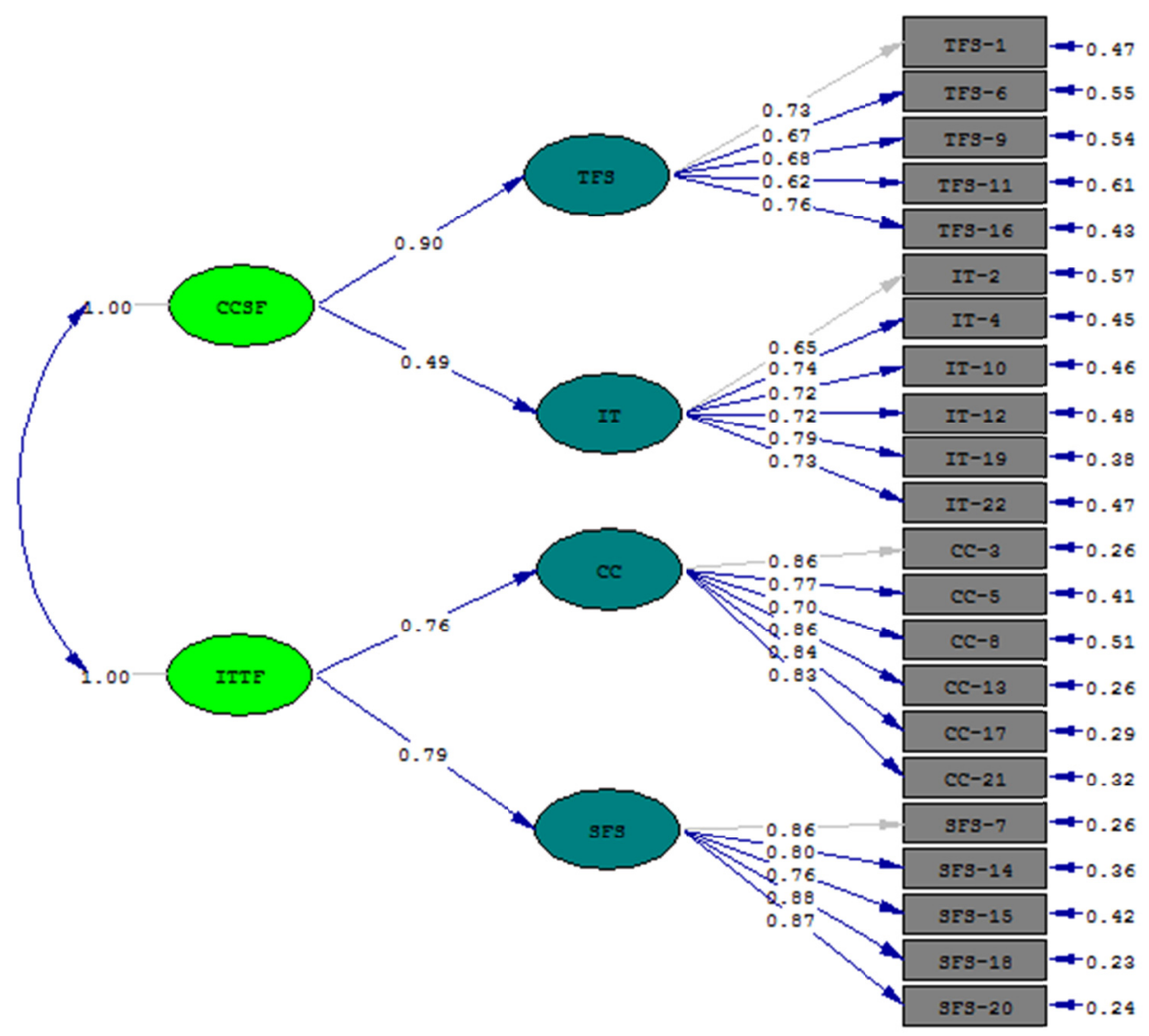

Figure 1. Parameters of standardized CFA 
All path coefficients were statistically significant at the .001 level. The correlation analysis results between two dimensions and four sub-factors are given on Table 6.

Table 6. Correlations among the dimensions and sub-factors

\begin{tabular}{|c|c|c|c|c|c|}
\hline & ITTF & TFS & IT & CCSF & SFS \\
\hline ITTF & 1 & & & & \\
\hline TFS & $.83^{*}$ & 1 & & & \\
\hline IT & $.84^{*}$ & $.39 *$ & 1 & & \\
\hline CCSF & $-.27^{*}$ & $-.27^{*}$ & $-.19 *$ & 1 & \\
\hline SFS & $-.24 *$ & $-.24 *$ & $-.22 *$ & $.88^{*}$ & 1 \\
\hline $\mathrm{CC}$ & $-.25^{*}$ & $-.24 *$ & $-.17 *$ & $.90^{*}$ & $.57 *$ \\
\hline
\end{tabular}

$* \mathrm{p}<.01$.

A high correlation was found between ITFF with TSF $(r=.83)$ and IT $(r=.84)$. There was also positive correlation between IT and TFS ( $r=.39)$. A high level correlation was also found among CCSF and its sub-factor SFS ( $\mathrm{r}=.88)$ and $\mathrm{CC}(\mathrm{r}=.90)$. There was a medium level correlation between SFS and CC $(\mathrm{r}=.57)$. The two dimensions exhibit a significant negative correlation $(\mathrm{r}=-.27)$. A negative significant correlation was among ITTF and CCSF dimensions and the four sub-factors (TFS, IT, SFS, CC). Analysis results of each sub-factor of pre-service teachers according to their disciplines, divided as soft and hard sciences, are given on Table 7.

Table 7. Result of $t$ Test analysis according to disciplines

\begin{tabular}{|c|c|c|c|c|c|c|c|}
\hline Sub-Factors and Dimensions & Disciplinary Differences & $\mathrm{N}$ & M & $\mathrm{Sd}$ & Std. Error M & $\mathrm{t}$ & $\mathrm{p}$ \\
\hline \multirow{3}{*}{ TFS } & Hard Science & 240 & 3.62 & .87 & .05625 & \multirow{3}{*}{.824} & \multirow{3}{*}{$.410^{*}$} \\
\hline & & & & & & & \\
\hline & Soft Science & 245 & 3.56 & .82 & .05251 & & \\
\hline \multirow{3}{*}{ IT } & Hard Science & 240 & 3.86 & .89 & .05806 & \multirow{3}{*}{.728} & \multirow{3}{*}{$.467^{*}$} \\
\hline & & & & & & & \\
\hline & Soft Science & 245 & 3.80 & .85 & .05409 & & \\
\hline \multirow{3}{*}{ SFS } & Hard Science & 240 & 3.33 & 1.08 & .06992 & \multirow{3}{*}{-3.356} & \multirow{3}{*}{$.001 * *$} \\
\hline & & & & & & & \\
\hline & Soft Science & 245 & 3.65 & .98 & .06302 & & \\
\hline \multirow{3}{*}{$\mathrm{CC}$} & Hard Science & 240 & 3.29 & 1.17 & .07606 & \multirow{3}{*}{-4.615} & \multirow{3}{*}{$.000 * *$} \\
\hline & & & & & & & \\
\hline & Soft Science & 245 & 3.76 & 1.05 & .06709 & & \\
\hline \multirow{3}{*}{ CCSF } & Hard Science & 240 & 3.31 & .95 & .06172 & \multirow{3}{*}{-4.543} & \multirow{3}{*}{$.000 * *$} \\
\hline & & & & & & & \\
\hline & Soft Science & 245 & 3.71 & .94 & .06019 & & \\
\hline \multirow{3}{*}{ ITTF } & Hard Science & 240 & 3.74 & .71 & .04610 & \multirow{3}{*}{.931} & \multirow{3}{*}{$.353^{*}$} \\
\hline & & & & & & & \\
\hline & Soft Science & 245 & 3.68 & .72 & .04590 & & \\
\hline
\end{tabular}

$\mathrm{df}=483 ; * \mathrm{p}>.05 ; * * \mathrm{p}<.05$.

According to the results, a meaningful difference was seen between the TFS and IT score means of pre-service teachers. In the SFS sub-factor, pre-service teachers in the soft sciences $(M=3.65)$ had a higher mean score than the pre-service teachers in the hard sciences $(M=3.33)(t=-3.356 ; \mathrm{p}<.05)$. Similarly, in the $C C$ sub-factor pre-service teachers' scores $(M=3.76)$ in the soft sciences were higher than the scores of pre-service teachers in the hard sciences $(\mathrm{M}=3.29)(\mathrm{t}=-4.615 ; \mathrm{p}<.05)$. The scores taken from the CCSF showed that pre-service 
teachers in the soft sciences had higher means than pre-service teachers in the hard sciences $(t=-4.543 ; \mathrm{p}<.05)$, however; for pre-service teachers' ITTF the scores showed no difference in respect of teachers' hard or soft science disciplines $(\mathrm{t}=.931 ; \mathrm{p}>.05)$.

\section{Discussion}

In this study, adaptation studies of the scale, by Prosser and Trigwell's (2006), were made. Originally the scale had a two factor structure. But in different studies, researchers found different factor structures in the cross-cultural adaptation (Stes et al. 2010). Meyer and Eley (2006) indicated that the scale should not be automatically analysed according to two or four factor models, as stated by the developers. Even though Prosser and Trigwell (2006) analyzed the scale from the data collected from four different countries, they stated that the usage was also based on the context. From this perspective, it was considered that analysing the scale in different contexts would be useful.

Stes et al. (2010), in the study done with the German version, had some problems originating from translation and reanalyzed data after retranslation. Meyer and Eley (2006) pointed out in a study they made in England and Australia that the scale has not reached the extent the writers stated. For this reason, the scale's problems emerged from the translation were minimized by providing linguistic equivalence. After the scale's Turkish translation was made, the scale's Turkish and English versions were applied to 40 pre-service teachers studying English Language Teaching. The analysis results, $t$ test and correlation analysis results obtained from the scale's Turkish and English versions indicated that linguistic equivalence of the scale was achieved. Negative correlations were found in both the Turkish and English versions of the scale's ITTF and CCSF dimensions.

The reliability results based on the scale's two dimensions and four factors structure were found to be high. In the reliability analysis related to their study Stes, Coertjens, and Van Petegem (2010) found Cronbach's Alpha value between .75 and .84 . In the analysis based on the two factors structure, which is the first version of the scale, Prosser and Trigwell determined a reliability value of .74 in the student based approach and .66 in the teacher based approach. Stes et al. (2010) determined the reliability value as .78 and .82. Trigwell (2012) determined the ATI-R reliability value for ITTF s 0.74 ; and for CCSF as 0.82 . The reliability values obtained from the Turkish sample were found to be higher. After the reliability analysis to determine the suitability of scale's factor structure, the CFA was conducted. The analysis results based on the two factors did not show a good fit with the data. Even though adjustments were made for error covariance, owing to the lack of improvement it was decided to test using the four structure models. It was determined that fit indices produced nearly perfect level values and that the AIC and CAIC indexes, which had a contribution to the model choice, produced a better value. It was determined that there was a negative meaningful correlation between the student-focused teaching approach and the teacher-focused teaching approach. It was also found that the pre-service teachers who had the teacher-focused approach conception showed a lower student-focused approach conception. In this respect, it could be said that the scale had the power to determine the changes in the teachers' teaching approaches.

It was determined that the scale with two dimensions and four sub-factors was more suitable for Turkish culture and it produced much more reliable results. It could be said that for the data obtained the model is more adequate The fit indices obtained from adopted scale were similar to Trigwell and Prosser (2006). It was determined that the scale's first version having two factors gave a poor fit. In addition to these, two dimensions with four sub-factors (CFI=998; TLI=989; RMSEA=.037; SRMR=.008) had better fit indices. Likewise, a negative correlation was determined between the ITTF and CCSF scales. Yet, Stes et al. (2010), in the analysis they did for the German version of the scale, determined that it was not appropriate for the two structure model. They ran the CFA again, which resulted in a five factor solution. According to these analyses, two factors were determined in the ITTF approach and three factors in the CCSF approach. A negative correlation was also found between the teacher- and student-focused approaches. Arenas (2009) found the reliability value for ITTF scale as .84, and for CCSF as 89 .

Although the ATI-R scale is not used in the classification of teachers and teacher candidate's teaching approaches, it is used to compare disciplinary differences in teachers in other studies (Lindblom-Ylänne et al., 2004; Lueddeke, 2003; Postareff et al., 2007). The results in the literature study and the results of this study show a similarity. Despite the fact that in this study the ITTF scale's TFS and IT sub-factors' differences were not determined, in the CCSF scale's CC and SFS sub-factors, it was determined that the students who studied hard science were more teacher-focused than students in the soft sciences, who display a more student-focused approach. This result supports the findings of Lindblom-Ylänne et al. (2006), Lueddeke (2003) and Stess et al. (2008). Hard discipline programs have a hierarchical and linear data structure unlike soft discipline programs 
which have a more flexible and spiral structure. In this case it could be said that there could be a difference in candidate teachers' teaching layout conception and understanding of the knowledge (Prosser \& Trigwell, 1999; Stes, Coertjens, \& Van Petegem, 2010). Neumann, Parry, and Becher (2002) draw attention to the fact that the separation of the disciplines is not superficial. Even though the teachers display a more student-focused teaching approach, from time to time they can use teacher-focused teaching approaches and strategies in teaching. Student-focused teaching approaches include teacher-focused strategies. Furthermore, it contains larger and various strategies beyond the teacher-focused strategies (Lindblom-Ylänne et al., 2004; Trigwell \& Prosser 1996).

The ATI is a context-bound scale based on cultural differences. Trigwell and Prosser's (2006) analysis results based on data collected from four countries are similar to the findings obtained from Turkish culture. However, neither the studies that Stes et al. (2010) and Meyer and Eley (2006) have done in England and Australia reached any different dimensions. This shows that the scale should not be used directly but it should be analysed by taking the cultural differences into account. It could be said that the scales, by which the data are collected from teachers working on different disciplines, may give different results in different measurements and in different times because of the cultural and linguistic differences.

The scale, which was developed to measure pre-service teachers' approach towards teaching, a basic limitation is that it is not intended to classify the teachers; it's aimed to understand the changes in teaching. For this reason, the scale can be used to determine the change for both pre-service teachers' education and in service training of the teachers. A scale is far from determining and classifying teachers' actions and thoughts aimed at teaching (Meyer \& Eley, 2006; Prosser \& Trigwell, 2006; Stes et al., 2010). Because of its being context-bound, it could be possible to get different scores taken by teachers working in different disciplines or in different teaching contexts. Therefore, considering the institution the teachers work at, the form of education they receive and the school policy towards the education discipline they received should be taken into account while using the scale. Even though the scale is used for understanding the change the teachers' conception for applied programmes, it does not allow a determination of the behaviour of teachers in a classroom. Pre-service teachers' classroom behaviours should be observed to define whether they use a student-focused teaching approach or a teacher-focused teaching approach. Trigwell and Prosser (2004) developed the ATI based on the qualitative data analysis collected from university teachers. But the scale revealed quantitative results. Gibbs and Coffey (2004) used the scale's first version to evaluate the influence of the education program. They determined a change that teachers were more likely to use a student focused approach as a result of the trainings. Lindblom-Ylanne et al. (2004) determined a difference in the teachers' teaching conceptions. Postareff et al. (2007) took into consideration the conception of changes from education given to the lecturers. It was determined that teachers receiving 30 credits and over had a high student focused approach and their teacher focus/information transmission approach was low. In the studies mentioned earlier, the scale shows an effective usage in the understanding of the change of the teachers' approach aimed at teaching.

While student-focused approach supports the development of deep understanding in students, in the teacher-focused approach, teacher transmit the information and students are more likely to adopt a surface approach to learning. For every situation, a linear relationship should not be expected between student-focused and teacher-focused teaching approaches (Trigwell and Prosser, 2004). Meyer and Eley (2006) and Norton Richardson, Hartley, Newstead, and Mayes (2005) argue that the ATI's implementation purposes and strategies are uncertain. Also they found it methodologically defective because of the fact that the analysis was made with the factor structure defined a priori. Postareff et al. (2008) studied university teachers' definitions of education and defined similar items with the ATI by qualitative analysis of the data. Coffey and Gibbs (2002) found a positive correlation between teaching methods and the student-focused approach of the ATI and a negative relationship with the teacher-focused approach. In the experimental study on the influence upon teachers' teaching approachess in the educational development program by Stes et al. (2010), it was determined that the qualitative and quantitative data support each other. The results of the study of the ATI show reliable results and it can be used for determining the changes in teacher's teaching approach. Both the findings obtained from this study and the research findings done in the literature show that it could be used in determining the change in the teachers' teaching approach.

\section{Conclusion}

In the study, the ATI-R's English and Turkish versions were applied to 40 Turkish pre-service teachers attending English Language Teaching Department. Correlation and $t$ test analyses of the data gathered from bilingual participants showed that the scale was linguistically equivalent. The CFA analysis based on two factors showed poor fit indices. However, the ATI-R based on a two dimension and four sub-factor structures showed better and 
adequate fit indices even without the inclusion of error covariances. The four sub-factor structures of ATI-R scale, consisting of 22 items, appear to be sufficiently internally consistent. Approaches to teaching have been studied in relation to context variables. Students divided two separate groups: hard and soft science. In the study statistically differences were found between pre-service students from the soft sciences and the hard sciences in the terms of the CCSF dimension and its sub-factors, CC and SFS. The analysis of data obtained from the ATI-R scale show reliable and valid results and it can be used for determining the changes in teacher's teaching approach.

\section{Recommendations}

Using a Turkish version of the scale to conduct a longitudinal study with educational faculty students, measuring their conceptual changes, could contribute to determining the degree to which the scale reflects changes in students' teaching approaches. The scale's suitability to Turkish culture could be analyzed for reliability and validity by including university instructors and teachers. Also by comparing and analyzing the results obtained from qualitative data from the scale could give better evidence for determining (or otherwise) changes in the teaching approach. On the other hand, it could be helpful to re-analyse the data based on instructors, teacher candidates and students working/studying in specific field.

\section{References}

Alkin-Sahin, S. (2015). The relationship between the educational beliefs and learning approaches Anthropologist, 22(2), 301-308.

Arenas, E. (2009). How teachers' attitudes affect their approaches to teaching international students. Higher Education Research \& Development, 28(6), 615-628. http://dx.doi.org/10.1080/07294360903208096

Banning, M. (2005). Approaches to teaching: Current opinions and related research. Nurse Education Today, 25(7), 502-508. http://dx.doi.org/10.1016/j.nedt.2005.03.007

Barr, R. B. \& Tagg, J. (1995). From teaching to learning-A new paradigm for undergraduate ducation. Change: The magazine of Higher Learning, 27(6), 12-26. http://dx.doi.org/10.1080/00091383.1995.10544672

Bentler, P. M. \& Bonett, D. G. (1980). Significance tests and goodness of fit in the analysis of covariance structures. Psychological Bulletin, 88, 588-606. http://dx.doi.org/10.1037/0033-2909.88.3.588

Biggs, J. B. (1979). Individual differences in study processes and the quality of learning outcomes. Higher Education, 8, 381-394. http://dx.doi.org/10.1007/BF01680526

Biggs, J. B. (1992). Why and how do Hong Kong students learn? Using the learning and study process questionnaires. Education paper no. 14, Faculty of Education, The University of Hong Kong.

Biggs, J. B. (1999). Teaching for quality learning at University. Buckingham: Open University Press.

Biggs, J. B. (2003). Teaching for quality learning at university: What the student does (2nd ed.). Ballmoor, UK: Society for Research into Higher Education \& Open University Press.

Bollen, K. A. (1989). A new incremental fit index for general structural equation models. Sociological Methods \& Research, 17(3), 303-316. http://dx.doi.org/10.1177/0049124189017003004

Brooks, J. G., \& Brooks, M. G. (1993). The case for constructivist classrooms. Alexandria, Va.: Association for Supervision and Curriculum Development.

Brown, T. A. (2006). Confirmatory factor analysis for applied research. New York: The Guilford Press

Büyüköztürk, Ş., Çokluk, Ö., \& Şekercioğlu, G. (2010). Sosyal bilimler için çok değişkenli istatistik: SPSS ve Lisrel uygulamalarl. Ankara: Pegem A yayıncilı.

Coffey. M., \& Gibbs, G. (2002). Measuring teachers' repertoire of teaching methods. Assessment \& Evaluation in Higher Education, 27(4), 383-390. http://dx.doi.org/10.1080/0260293022000001382

Entwistle, N. \& Ramsden, P. (1983). Understanding student learning. London: Croom Helm.

Ertmer, P. A., \& Newby, T. J. (1993). Behaviorism, cognitivism, constructivism: Comparing critical features from an instructional design perspective. Performance Improvement Quarterly, 6(4), 50-72. http://dx.doi.org/10.1111/j.1937-8327.1993.tb00605.x

Fenstermacher, G. D., \& Soltis, J. F. (2004). Approaches to teaching. Amesterdam Avenue, New York, NY: Teachers College press.

Friedlan, J. M. (1995). The effects of different teaching approaches on students' perceptions of the skills needed 
for success in accounting courses and by practicing accountants. Issues in Accounting Education, 10(1), 47-63.

Geisinger, K. F. (1994). Cross-cultural normative assessment: Translation and adaptation issues influencing the normative interpretation of assessment instruments. Psychological assessment, 6(4), 304-312. http://dx.doi.org/10.1037/1040-3590.6.4.304

Gibbs, G., \& Coffey, M. (2004). The impact of training of university teachers on their teaching skills, their approach to teaching and the approach to learning of their students. Active Learning in Higher Education, 5(1), 87-100. http://dx.doi.org/10.1177/1469787404040463

Gow, L., \& Kember, D. (1993). Conceptions of teaching and their relationship to student learning. Br. J. Educ. Psychol, 63, 20-33. http://dx.doi.org/10.1111/j.2044-8279.1993.tb01039.x

Gürol, M. (2005). Oluşturmacı öğrenme yaklaşımının uzmanlaşmaya etkisi. The Turkish Online Journal of Educational Technology, 4(1), 141-145.

Ho, A. (1998). Changing teachers' conceptions of teaching as anapproach to enhancing teaching and learning intertiary education (Unpublished Ph.D. thesis). University of Hong Kong

Ho, A., Watkins, D., \& Kelly, M. (2001). The conceptual change approach to improving teaching and learning: An evaluation of a Hong Kong staff development programme. Higher Education, 42(42), 143-169. http://dx.doi.org/10.1023/A:1017546216800

Hoyle, R. H. (Ed.). (1995). Structural equation modeling: Concepts, issues, and applications. Thousand Oaks, California: Sage Publications.

Jonassen, D. H. (1990). Thinking technology: Chaos in instructional design. Educational Technology, 30(2), 32-34.

Jöreskog, K. G., \& Sörbom, D. (1996). LISREL 8: User's reference guide. Scientific Software International.

Karataş, H., \& Erden, M. (2012). Akademik motivasyon ölçeğinin dilsel eşdeğerlik, geçerlik ve güvenirlik çalışması. E-Journal of New World Sciences Academy, Education Sciences, 7(4), 983-103.

Kember, D., \& Gow, L. (1994). Orientations to teaching and their effect on the quality of student learning. Journal of Higher Education, 65, 58-74. http://dx.doi.org/10.2307/2943877

Kember, D., \& Kwan, K. P. (2000). Lecturers' approaches to teaching and their relationship to conceptions of good teaching. Instructional Science, 28, 469-490. http://dx.doi.org/10.1007/978-94-010-0593-7_10

Kember, D., \& Kwan, K. P. (2002). Lecturers' approaches to teaching and their relationship to conceptions of good teaching. In N. Hativa, \& P. Goodyear (Eds.), Teacher thinking, beliefs and knowledge in higher education (pp. 219-240), Dordrecht: Kluwer.

Kember, D. (1997). A reconceptualisation of the research into university academics' conceptions of teaching. Learning and Instruction, 7(3), 255-275. http://dx.doi.org/10.1016/S0959-4752(96)00028-X

Kline, R. B. (2011). Principles and pracitce of structural equation modeling. NY: The Guilford Press.

Lindblom-Ylänne, S., Trigwell, K., Nevgi, A., \& Ashwin, P. (2004). Variation in approaches to teaching: The role of discipline and teaching context. Paper presented at the EARLI SIG Higher Education conference, June 18-21.

Lindblom-Ylänne, S., Trigwell, K., Nevgi, A., \& Ashwin, P. (2006). How approaches to teaching are affected by discipline and teaching context. Studies in Higher Education, 31, 285-298. http://dx.doi.org/10.1080/03075070600680539

Lueddeke, G. R. (2003). Professionalising teaching practice in higher education: A study of disciplinary variation and teaching-scholarship. Studies in Higher Education, 28, 213-228. http://dx.doi.org/10.1080/0307507032000058082

Meyer, J. H. F., \& Eley, M. G. (2006). The Approaches to Teaching Inventory: A critique of its development and applicability. British Journal of Educational Psychology, $\quad 76, \quad 633-649$. http://dx.doi.org/10.1348/000709905X49908

Neumann, R., Parry, S., \& Becher, T. (2002). Teaching and learning in their disciplinary contexts: A conceptual analysis. Studies in higher education, 27(4), 405-417. http://dx.doi.org/10.1080/0307507022000011525

Nevgi, A., Postareff, L., \& Lindblom-Ylänne, S. (2004). The effect of discipline on motivationalnd selfefficacy 
beliefs and on approaches to teaching of Finnish and English university teachers. Paper presented at the EARLI SIG higher education conference, June 18-21.

Norton, L., Richardson, J. T. E., Hartley, J., Newstead, S., \& Mayes, J. (2005). Teachers' beliefs and intentions concerning teaching in higher education. Higher Education, 50, 537-571. http://dx.doi.org/10.1007/s10734-004-6363-z

Özgüven, İ. E. (1994). Psikolojik testler. Ankara: Yeni Doğuş Matbaası.

Postareff, L., \& Lindblom-Ylänne, S. (2008). Variation in teachers' descriptions of teaching: Broadening the understanding of teaching in higher education. Learning and Instruction, 18(2), 109-20. http://dx.doi.org/10.1016/j.learninstruc.2007.01.008

Postareff, L., Lindblom-Ylänne, S., \& Nevgi, A. (2007). The effect of pedagogical training on teaching in higher education. Teaching and Teacher Education, 23, 557-71. http://dx.doi.org/10.1016/j.tate.2006.11.013

Prosser, M., \& Trigwell, K. (1993). Development of an approaches to teaching questionnaire. Research and Development in Higher Education, 15, 468-473.

Prosser, M., \& Trigwell, K. (1996). Approach to Teaching Inventory. University of Sydney, Unpublished test.

Prosser, M., \& Trigwell, K. (1997). Relations between perceptions of the teaching environment and approaches to teaching. British Journal of Educational Psychology, 67, 25-35. http://dx.doi.org/10.1111/j.2044-8279.1997.tb01224.x

Prosser, M., \& Trigwell, K. (2006). Confirmatory factor analysis of the Approaches to Teaching Inventory. British Journal of Educational Psychology, 76(2), 405-419. http://dx.doi.org/10.1348/000709905X43571

Prosser, M., \& Trigwell, K. (1999). Understanding learning and teaching: The experience in higher education. UK: McGraw-Hill Education.

Prosser, M., Trigwell, K. \& Taylor, P. (1994). A phenomenographic study of academics' conceptions of science learning and teaching. Learning and Instruction, 4(3), 217-231. http://dx.doi.org/10.1016/0959-4752(94)90024-8

Savaşır, I. (1994). Ölçek uyarlamasındaki sorunlar ve bazı çözüm önerileri. Türk Psikoloji Dergisi, 9(33), 27-32.

Schellhase, K. C. (2009). Are approaches to teaching and/or student evaluation of instruction scores related to the amount of facultyformal educational course work? (Unpublished $\mathrm{PhD}$ dissertation). College of Education at the University of Central Florida Orlando, Florida.

Singer, E. (1996). Espoused teaching paradigms of college faculty. Research in Higher Education, 37, 659-679. http://dx.doi.org/10.1007/BF01792951

Stes, A., \& Van Petegem, P. (2014). Profiling approaches to teaching in higher education: A cluster-analytic study. Studies in Higher Education, 39(4), 644-658. http://dx.doi.org/10.1080/03075079.2012.729032.

Stes, A., Coertjens, L., \& Van Petegem, P. (2010). Instructional development for teachers in higher education:

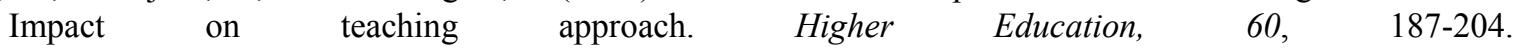
http://dx.doi.org/10.1007/s10734-009-9294-x.

Stes, A., De Maeyer, S., \& Van Petegem, P. (2010). Approaches to teaching in higher education: Validation of a Dutch version of the Approaches to Teaching Inventory. Learning Environments Research, 13(1), 59-73. http://dx.doi.org/10.1007/s10984-009-9066-7

Stes, A., Gijbels, D., \& Van Petegem, P. (2008). Student-focused approaches to teaching in relation to context and teacher characteristics. Higher Education, 55, 255-267. http://dx.doi.org/10.1007/s10734-007-9053-9

Tabachnick, B., \& Fidell, L. (1989). Using multivariate statistics. Northedge: Harper Collins.

Tavşancıl, E. (2002). Tutumların ölçülmesi ve SPSS ile veri analizi. Ankara: Nobel Yayın Dağıtım.

Tekin, H. (1996). Ĕgitimde ölçme ve değerlendirme. Ankara: Yargı yayınları, no: 17.

Tezci, E., \& Gürol, A. (2003). Oluşturmacı öğretim tasarımı ve yaratıcılık [Constructivist instructional design and creativity]. The Turkish Online Journal of Educational Technology-TOJET, 2(1), 8-16.

Trigwell, K, Prosser, M., \& Ginns, P. (2005). Phenomenographic pedagogy and a revised approaches to teaching inventory. Higher Education Research \& Development, 24(4), 349-360. http://dx.doi.org/10.1080/07294360500284730

Trigwell, K., \& Prosser, M. (1991). Improving the quality of student learning: The influence of learning context 
and student approaches to learning on learning outcomes. Higher Education, 22(3), 251-266. http://dx.doi.org/10.1007/BF00132290

Trigwell, K., \& Prosser, M. (1993). Approaches adopted by teachers of first year university science courses. Research and Development in Higher Education, 14, 223-228.

Trigwell, K., \& Prosser, M. (1996). Congruence between intention and strategy in university science teachers' approaches to teaching. Higher Education, 32, 77-87. http://dx.doi.org/10.1007/BF00139219

Trigwell, K., \& Prosser, M. (2004). Development and use of the Approaches to Teaching Inventory. Educational Psychology Review, 16(4), 409-424. http://dx.doi.org/10.1007/s10648-004-0007-9

Trigwell, K., \& Prosser, M., \& Waterhouse, F. (1999). Relations between teachers' approaches to teaching and students' approaches to learning. Higher Education, 37, 57-70. http://dx.doi.org/10.1023/A:1003548313194.

Trigwell, K. (2002). Approaches to teaching design subjects: A quantitative analysis. Art, Design and Communication in Higher Education, 1, 69-80. http://dx.doi.org/10.1386/adch.1.2.69

Trigwell, K. (2012). Relations between teachers' emotions in teaching and their approaches to teaching in higher education. Instr Sci, 40, 607-621. http://dx.doi.org/10.1007/s11251-011-9192-3

Trigwell, K., Prosser, M., \& Taylor, P. (1994). Qualitative differences in approaches to teaching first year university science. Higher Education, 27, 75-84. http://dx.doi.org/10.1007/BF01383761

Trigwell, K., Prosser, M., Martin, E., \& Ramsden, P. (2000). Discipline differences in relations between learning, teaching and ways of leading teaching departments. In C. Rust (Ed.), Improving student learning 7: Improving student learning through the disciplines (pp. 502-509). Headington: Oxford Centre for Staff and Learning Development.

Weimer, M. E. (1988). Ideas for managing your classroom better. The Teaching, 2(2), 3-4.

Wentzel, K. R. (2002). Are effective teachers like good parents? Teaching styles and student adjustment in early adolescence. Child Development, 73, 287-301. http://dx.doi.org/10.1111/1467-8624.00406

Wilson, S. M., \& Berne, J. (1999). Teacher learning and the acquisition of professional knowledge: An examination of research on contemporary professional development. In A. Iran-Nejad, \& P. D. Pearson (Eds.), Review of research in education (pp. 173-209). Washington, DC: AERA.

Yanpar-Yelken, T., \& Kılıç, Ç. (2010). Changes to the curriculum of primary schools in Turkey: The perceptions of teachers. NWSA: Education Sciences, 5(1), 348-366.

Zhang, L. F., \& Sternberg, R. J. (2001). Thinking styles across cultures: Their relationships with student learning. In R. J. Sternberg, \& L. F. Zhang (Eds.), Perspectives on thinking, learning, and cognitive styles (pp. 197-226). Mahwah, NJ: Lawrence Erlbaum.

Zhang, L. F. (2001a). Approaches and thinking styles in teaching, The Journal of Psychology, 135(5), 547-561. http://dx.doi.org/10.1080/00223980109603718

Zhang, L. F. (2001b). Approaches and thinking styles in teaching. Journal of Psychology, 135(5), 547-561.

Zhang, L. F. (2004). Do university students' thinking styles matter in their preferred teaching approaches? Personality and Individual Differences, 37, 1551-1564. http://dx.doi.org/10.1016/j.paid.2004.02.012

\section{Copyrights}

Copyright for this article is retained by the author(s), with first publication rights granted to the journal.

This is an open-access article distributed under the terms and conditions of the Creative Commons Attribution license (http://creativecommons.org/licenses/by/4.0/). 